JMPF Vol. 9 No. 3 : 151-163

ISSN-p : 2088-8139

ISSN-e : 2443-2946

DOI : $10.22146 /$ jmpf.41599

\title{
Korelasi Pelayanan Kefarmasian dan Citra Rumah Sakit dalam Analisa SWOT Instalasi Farmasi RS Baptis Batu
}

\author{
Correlation between Pharmaceutical Care and Hospital Image in SWOT Analysis of Pharmaceutical \\ Installation of Baptis Batu Hospital
}

Charina Halim Sugiono, Rollando, FX. Haryanto Susanto, Eva Monica*

Prodi Farmasi, Fakultas Sains dan Teknologi Universitas Ma Chung

Submitted: 12-5-2019 Revised: 5-27-2019
Korespondensi : Eva Monica : Email : eva.monica@machung.ac.id

Accepted: 9-24-2019

\begin{abstract}
ABSTRAK
Pelayanan kefarmasian yang baik diharapkan dapat mempengaruhi dan membentuk citra rumah sakit yang baik pula. Hal ini menyangkut peningkatan competitive advantage antar rumah sakit. Tujuan penelitian ini adalah mengetahui pengaruh tiga dimensi pelayanan kefarmasian yakni relasi interpersonal, manajemen terapi dan kepuasan umum terhadap citra RS Baptis untuk kemudian melakukan perumusan analisis strategi menggunakan SWOT sehingga RS Baptis Batu dapat meningkatkan competitive advantage. Penelitian dilakukan menggunakan metode kuantitatif dan kualitatif. Penelitian kuantitatif melibatkan 200 responden dan diolah menggunakan regresi linear berganda guna melihat pengaruh pelayanan kefarmasian terhadap citra rumah sakit. Hasil penelitian membuktikan bahwa tenaga kefarmasian di Instalasi Farmasi Rawat Jalan RS. Baptis Batu sudah memberikan pelayanan yang baik, memberikan kepedulian terhadap pasien, menunjukkan sikap menghormati dan memberi kesediaannya untuk kegiatan informasi, edukasi, konseling dengan baik. Sementara itu rating yang tergolong rendah, tetapi masih pada rentang baik adalah waktu tunggu obat pasien yang berada dalam dimensi kepuasan pasien secara umum. Penelitian kualitatif menggunakan metode SWOT yang melibatkan apoteker di Instalasi Farmasi Rumah Sakit Baptis Batu. Hasil penelitian statistik menunjukkan bahwa secara simultan maupun parsial ketiga dimensi pelayanan kefarmasian berpengaruh positif terhadap citra rumah sakit. Analisis SWOT RS Baptis Batu yang dilakukan peneliti menunjukkan rumah sakit berada pada kuadran satu, artinya bahwa rumah sakit menjalankan strategi yang mengarah kepada pertumbuhan rumah sakit, yang berarti rumah sakit berada pada posisi sempurna sehingga dapat mengandalkan kekuatan yang dimiliki untuk berkembang dengan pesat.
\end{abstract}

Kata kunci: Pelayanan kefarmasian; keunggulan bersaing; analisis SWOT

\section{ABSTRACT}

Good pharmacy services are expected to build the positive image of the hospital. This includes the enhancement of competitive advantage among hospitals. The expected output of this research is identifying the effect of three dimensions of pharmacy services; interpersonal relations, therapy management and general satisfaction, to the image of the Baptis hospital, Batu City. The implementation of SWOT analysis is expected to determine the effect between variables, and the hospital can improve the competitive advantage. This study used quantitative and qualitative methods. Quantitative research involved 200 respondents and the method of statistical analysis was Multiple Linear Regression to investigate the effect of pharmacy services on the hospital image. The results of the study prove that pharmacy personnel at the Pharmacy Installation of Baptist Hospital Batu has provided good service, cared for patients, showed respect, and gave their willingness to provide information, education, counseling, and good activities. While the rating is classified as low, but still in good range is the patient's response time which is in the dimensions of general patient satisfaction. Qualitative research used the SWOT analysis and involved pharmacists of the Baptis Hospital. Generally, the result of statistical analysis revealed that the dimensions of pharmacy services have a positive effect on the hospital hospital image, both partially and simultaneously. In addition, the result of SWOT analysis demonstrated that Baptis Hospital is included in the first quadrant, which means the hospital runs a strategy that leads to the growth of the hospital. The hospital is in the perfect position that allows the management to rely on the strength in order to develop rapidly.

Keywords: Pharmaceutical Care; Competitive Advantage; SWOT Analysis

\section{PENDAHULUAN}

Rumah sakit menurut WHO (World Health Organization) adalah bagian integral dari suatu organisasi sosial dan kesehatan dengan fungsi menyediakan pelayanan paripurna (komprehensif), penyembuhan penyakit (kuratif) dan pencegahan penyakit (preventif) kepada masyarakat. Salah satu pelayanan bagi masyarakat ialah pelayanan kefarmasian yang ada di setiap rumah sakit. Peraturan Menteri Kesehatan nomor 72 Tahun 2016, menyatakan bahwa pelayanan kefarmasian adalah suatu pelayanan langsung dan bertanggung jawab kepada pasien yang 
berkaitan dengan sediaan farmasi dengan maksud mencapai hasil yang pasti untuk meningkatkan mutu kehidupan pasien. Data dan informasi Kementerian Kesehatan Republik Indonesia 2016 menunjukkan bahwa Jawa Timur memiliki jumlah rumah sakit sebanyak 377, baik rumah sakit umum maupun rumah sakit khusus. Pertumbuhan rumah sakit ini menimbulkan kompetisi yang semakin ketat. Hal ini semakin memicu suatu rumah sakit untuk meningkatkan hospital image, sehingga competitive advantage dari rumah sakit tersebut meningkat. Merek dan citra merek sering memainkan peran kunci dalam keunggulan kompetitif dan dapat membawa nilai dan laba yang signifikan bagi organisasi, dengan demikian, meningkatkan keunggulan kompetitif ${ }^{1}$.

Beberapa penelitian tentang kualitas pelayanan dan korelasinya dengan citra perusahaan telah dilakukan. Penelitian oleh Singh pada tahun 2013 menemukan bahwa kompetisi global telah membuat suatu organisasi jasa untuk memberikan varian kualitas yang dapat mendukung bertambahnya kepuasan konsumen yang berpengaruh dalam membangun suatu citra dan reputasi yang baik, maka organisasi penyedia jasa harus berkomitmen terhadap nilai kualitas normatif ${ }^{2-4}$. Penelitian lain oleh Polat mengatakan satu pelayanan yang buruk dapat merubah citra perusahaan dari positif menjadi citra yang dipandang negatif. Jadi jelas bahwa kualitas dari jasa yang disediakan kepada konsumen akan mempengaruhi positif dan negatifnya citra perusahaan ${ }^{5-7}$. Pencitraan merupakan sebuah tahapan penting bagi rumah sakit karena dapat mendorong kesetiaan pelanggan ${ }^{8,9}$. Suatu citra merek (brand image) juga memainkan peran penting dalam keunggulan bersaing (competitive advantage) karena dapat membawa nilai dan keuntungan yang signifikan bagi sebuah organisasi ${ }^{10}$, maka dari itu organisasi kesehatan harus membentuk layanan yang berkualitas secara terus menerus sehingga dapat meningkatkan citra mereka ${ }^{11}$.

Rumah Sakit Baptis Batu merupakan salah satu rumah sakit swasta di Kota Batu,
Jawa Timur yang sedang berkembang untuk memperbaiki mutu pelayanan kepada pasiennya guna menjamin kepuasan pasien terhadap pelayanan kefarmasiannya. Berdasarkan data yang telah disampaikan di atas, maka pengukuran kepuasan pasien terhadap pelayanan kefarmasian dan pengaruhnya terhadap citra rumah sakit serta analisis strategi dengan SWOT dinilai penting untuk Rumah Sakit Baptis Batu sebagai peningkat daya saing untuk mencapai competitive advantage. Beberapa penelitian tentang perumusan strategi telah dilakukan, salah satunya adalah yang dilakukan oleh Tjia Fie Tjoe dan Harjadi Sarjono yang merumuskan strategi diversifikasi yang mengarah pada pertumbuhan dan stabilitas ${ }^{12}$. Hal ini diperlukan supaya Rumah Sakit Baptis Batu dapat bertahan dalam persaingan dan terus melakukan continuous improvement.

\section{METODE}

Penelitian dilakukan di Instalasi Farmasi Rawat Jalan Rumah Sakit Baptis Batu dengan melibatkan pasien farmasi rawat jalan dan apoteker di Instalasi Farmasi Rumah Sakit Baptis Batu

\section{Jenis Penelitian}

Penelitian yang dilakukan merupakan penelitian non-eksperimental dan termasuk penelitan deskriptif. Penelitian ini mengggunakan pendekatan kualitatif dan kuantitatif untuk menunjukkan hubungan sebab akibat, sehingga dalam penelitian ini terdapat variabel independen dan dependen ${ }^{13}$. Peneliti ingin melihat hubungan sebab akibat antara beberapa variabel yaitu Hubungan Interpersonal/Interpersonal relationship (X1), Manajemen Terapi/Managing therapy (X2), dan kepuasan pasien secara umum/General satisfaction $(\mathrm{X} 3)^{14,15}$ dengan Citra Rumah Sakit Baptis Batu/Hospital Image (Y). Penelitian ini menggunakan media kuesioner untuk mendapatkan data kepuasan pasien.

Dalam penelitian ini populasi adalah pasien Rumah Sakit Baptis Batu yang mendapatkan pelayanan di Rawat Jalan Instalasi Farmasi Rumah Sakit Baptis Batu. 
Angka populasi pasien rawat jalan Rumah Sakit Baptis Batu mencapai kurang lebih 80 hingga 100 pasien dalam 1 hari. Penelitian ini menggunakan teknik sampling NonProbability Sample dengan metode purposive sampling. Sampel juga harus memenuhi kriteria inklusi yang telah ditentukan sebagai berikut:

1. Pasien yang mendapatkan layanan rawat jalan di Instalasi Farmasi Rumah Sakit Baptis Batu

2. Memiliki umur antara 17 tahun hingga 65 tahun

3. Pasien dengan riwayat penyakit kronis (diabetes mellitus, hipertensi, jantung, asma, PPOK, epilepsi, schizophrenia, stroke, lupus)

4. Kunjungan rawat jalan di Instalasi Farmasi Rumah Sakit Baptis Batu minimal 2 kali dalam satu tahun terakhir

5. Pernah berkunjung ke rawat jalan Instalasi Farmasi Rumah Sakit lainnya/ selain di Rumah Sakit Baptis Batu minimal 2 kali

Berikut adalah teknik pengambilan populasi pasien menggunakan teknik purposive sampling 13

$$
n=\frac{N}{N e^{2}+1}
$$

Keterangan: $\mathrm{n}=$ Banyaknya unit sampel; $\mathrm{N}=$ Banyaknya Populasi; e = Taraf Nyata $(0,1) ; 1=$ Bilangan konstanta

Berikut adalah perhitungan sampel:

$\mathrm{N}=3.10$

$\mathrm{e}=$ ditetapkan 0,1 yaitu penyimpangan dalam pemakaian sampel sebesar $10 \%$

1 = Bilangan Konstanta

Demikian dapat diketahui besarnya sampel sebagai berikut:

$$
\begin{gathered}
n=\frac{3.100}{(3.100) \cdot(0,1)^{2}+1} \\
n=96,875 \text { dibulatkan menjadi } 97
\end{gathered}
$$

Berdasarkan hasil perhitungan sampel, maka dapat diketahui bahwa banyaknya responden yang akan diteliti pada pengambilan sampel secara purposive sampling dari populasi pasien Rumah Sakit Baptis Batu sebanyak 97 sampel (orang). Namun menurut Umam tahun 2006 kebanyakan penelitian mengacu pada maksimal sampel yakni 500 sampel, maka pada penelitian ini diambil sampel sebanyak 200 dengan alasan agar hasil yang didapatkan lebih representatif.

\section{Uji Instrumen}

Pengujian instrument penelitian dilakukan dengan uji validitas dan reliabilitas untuk menunjukkan kesahihan suatu instrument. Instrumen dikatakan valid jika instrument tersebut dapat digunakan untuk mengukur apa yang hendak diukur ${ }^{13}$. Uji Reliabilitas adalah alat untuk mengukur suatu kuisioner yang merupakan indikator dari konstruk. Suatu kuisioner dikatakan reliabel atau handal jika jawaban seseorang terhadap pernyataan adalah konsisten atau stabil dari waktu ke waktu. Reliabilitas suatu test merujuk pada derajat stabilitas, konsistensi, daya prediksi, dan akurasi ${ }^{16}$. Uji dilakukan dengan membandingkan angka Cronbach alpha dengan ketentuan nilai Cronbach alpha minimal adalah 0.7 artinya jika nilai Cronbach alpha yang didapatkan dari hasil perhitungan SPSS lebih besar dari 0.7 maka disimpulkan kuisioner tersebut reliabel.

\section{Uji Asumsi Klasik}

Uji Normalitas

Pengujian normalitas memiliki tujuan untuk menguji apakah dalam model regresi data terdistribusi normal. Model regresi yang baik akan menunjukkan hasil ketika distribusi datanya normal atau mendekati normal. Uji normalitas pada penelitian ini menggunakan uji Kolmogorov-Smirnov.

\section{Uji Heteroskedastisitas}

Uji heteroskedastisitas digunakan untuk menguji apakah dalam suatu model regresi terjadi ketidaksamaan varians dari residual untuk suatu pengamatan ke pengamatan lainnya. Apabila yang terjadi varian residual pada suatu pengamatan ke pengamatan lain tetap dan atau memiliki karakteristik yang sama maka disebut 
Homokedastisitas. Apabila varian dari satu pengamatan ke pengamatan lainnya tidak tetap dan atau tidak memiliki karakteristik yang sama maka disebut Heteroskedastisitas. Model regresi yang baik adalah tidak terjadi heteroskedastisitas. Pada penelitian ini untuk mendeteksi adanya heteroskedastisitas pada data dilakukan uji Glejser yang merupakan nilai prediksi variabel dependen yaitu ZPRED dengan residunya yakni SRESID. Dasar pengambilan keputusan yang dilihat dari uji Glejser adalah ketika nilai sig variabel bebas $>$ 0,05 (alpha), maka pada model regresi tidak terjadi heteroskedastisitas.

\section{Uji multikolinearitas}

Uji multikolinearitas dilakukan untuk mengetahui apakah dalam model regresi terdapat korelasi antar variabel independen. Indikator yang digunakan untuk mendeteksi hal tersebut dilihat dari nilai Tolerance dan VIF. Tidak adanya multikolinearitas ditandai dengan nilai Tolerance $>0,10$ dan nilai VIF $<$ 10,00 .

\section{Uji Analisis Regresi Linear Berganda}

Analisis regresi linear berganda digunakan untuk mengetahui hubungan atau pengaruh variabel independen, yaitu $X_{1}$ Hubungan Interpersonal, $X_{2}$ Manajemen Terapi, $X_{3}$ Kepuasan Pasien terhadap hospital image atau citra Rumah Sakit Baptis Batu

Analisis regresi berganda dihitung dengan menggunakan rumus sebagai berikut:

$$
\mathrm{Y}_{1}=\mathrm{a}+\mathrm{b}_{1} \mathrm{X}_{1}+\mathrm{b}_{2} \mathrm{X}_{2}+\mathrm{b}_{3} \mathrm{X}_{3}
$$

Keterangan : $Y_{1}=$ Citra Rumah Sakit; $a=$ konstanta; $b_{1}, \ldots, b_{3}=$ koefisien regresi variabel independen; $X_{1}=$ Manajemen terapi; $X_{2}=$ Hubungan Interpersonal; $X_{3}=$ Kepuasan umum.

\section{Uji Hipotesis}

Suatu citra merek (brand image) juga memainkan peran penting dalam keunggulan bersaing (competitivee advantage) karena dapat membawa nilai dan keuntungan yang signifikan bagi sebuah organisasi ${ }^{10}$, maka dari itu organisasi kesehatan harus membentuk layanan yang berkualitas secara terus menerus sehingga dapat meningkatkan citra mereka ${ }^{11}$. Ekiz menemukan bahwa organisasi layanan kehilangan rata-rata $20 \%$ pelanggannya per tahun dan sebagian besar kerugian tersebut disebabkan oleh penurunan kualitas layanan ${ }^{17}$. Namun sebenarnya pelanggan dapat mengubah prespektif buruk suatu organisasi dengan mengubah citra organisasi tersebut menjadi lebih positif5. Oleh karena itu jelas bahwa kualitas layanan yang diberikan akan mempengaruhi citra suatu organisasi. Dengan demikian untuk membangun citra dan reputasi yang baik, organisasi layanan harus berkomitmen terhadap budaya layanan yang berkualitas terhadap pelanggannya ${ }^{7}$. Dengan demikian, ada alasan rasional untuk berteori hipotesis berikut:

$\mathrm{H}_{1}$ : Kepuasan Pelayanan Kefarmasian berpengaruh positif terhadap citra rumah sakit; $\mathrm{H}_{1 . a}$ : Kepuasan Pelayanan Kefarmasian pada dimensi hubungan interpersonal berpengaruh positif terhadap citra rumah sakit; H1.b : Kepuasan Pelayanan Kefarmasian pada dimensi manajemen terapi berpengaruh positif terhadap citra rumah sakit; $\mathrm{H}_{1 . c}$ Kepuasan Pelayanan Kefarmasian pada dimensi kepuasan pasien berpengaruh positif terhadap citra rumah sakit; $\mathrm{H}_{0}$ : Kepuasan Pelayanan Kefarmasian tidak berpengaruh positif terhadap citra rumah sakit; $\mathrm{H}_{0 . a}$ : Kepuasan Pelayanan Kefarmasian pada dimensi hubungan interpersonal tidak berpengaruh positif terhadap citra rumah sakit; Ho.b : Kepuasan Pelayanan Kefarmasian pada dimensi manajemen terapi tidak berpengaruh positif terhadap citra rumah sakit; $\mathrm{H}_{0 . c}$ : Kepuasan Pelayanan Kefarmasian pada dimensi kepuasan pasien tidak berpengaruh positif terhadap citra rumah sakit.

Secara statistik, penelitian ini dapat diukur dengan uji koefisien regresi (uji F) dan pengujian signifikan parameter individual (uji t). Hasil perhitungan statistik akan disebut signifikan menurut statistik, apabila uji nilai 
statistiknya berada dalam daerah kristis (dimana Ho ditolak). Sebaliknya hasil akan disebut tidak signifikan bila uji nilai statistiknya berada dalam daerah Ho diterima.

\section{Uji Signifikan Parsial (Uji t)}

Tujuan dari pengujian ini untuk mengetahui signifikan atau tidak pengaruh dari masing-masing variabel bebas $(X)$ terhadap variabel terikat $(\mathrm{Y})$. Uji ini juga digunakan dalam menguji $\mathrm{H}_{1.1}, \mathrm{H}_{1.2}, \mathrm{H}_{1.3}, \mathrm{H}_{2.1}$, $\mathrm{H}_{2,2}$, $\mathrm{H}_{2.3}$. Dasar pengambilan keputusan dalam penelitian ini adalah jika nilai sig lebih kecil dari nilai probabilitas 0,05, maka $\mathrm{H}_{1}$ diterima dan $\mathrm{H}_{0}$ ditolak.

\section{Uji Signifikan Simultan (Uji F)}

Pengujian secara simultan dalam penelitian ini digunakan untuk menguji secara signifikan pengaruh variabel independennya yang terdiri dari Hubungan Interpersonal/Interpersonal relationship (X1), Manajemen Terapi/Managing therapy (X2), dan kepuasan pasien secara umum/General satisfaction (X3) terhadap variabel dependen Citra Rumah Sakit Baptis Batu/Hospital Image (Y). Tujuannya adalah mengambil keputusan apakah model regresi linier berganda dapat digunakan atau tidak sebagai model analisis dalam penelitian.

Selain penelitian menggunakan kuesioner, dalam penelitian ini juga melibatkan proses wawancara kepada apoteker instalasi farmasi, yang meliputi:

\section{Wawancara}

Melakukan proses wawancara kepada apoteker instalasi farmasi mengenai faktor yang mempengaruhi perkembangan IFRS.

\section{Analisis Matriks IFE}

Melakukan analisis atau pemetaan Internal Factor Evaluation dari hasil wawancara yang dapat menggambarkan kondisi internal perusahaan, terdiri dari kekuatan dan kelemahan, serta perhitungan rating dan bobot.

\section{Analisis Matriks EFE}

Melakukan analisis atau pemetaan Eksternal Factor Evaluation dari hasil wawancara yang dapat menggambarkan kondisi eksternal perusahaan, terdiri dari peluang dan ancaman, serta perhitungan rating dan bobot.

\section{Analisis Matriks SWOT}

Pada tahap ini dilakukan analisis dan identifikasi dari kondisi internal-eksternal yang didapatkan dari EFE dan IFE dan telah dikaji dengan melibatkan pihak manajemen Instalasi Farmasi Rawat Jalan Rumah Sakit Baptis Batu. Perumusan strategi akan dilakukan dengan menggunakan matriks SWOT. Berdasarkan kekuatan, kelemahan, peluang dan ancaman yang diperoleh melalui audit internal dan eksternal, dapat diformulasikan alternative strategi yang diambil. Formulasi strategi dilakukan dengan menggunakan analisis SWOT.

\section{HASIL DAN PEMBAHASAN Hasil Penelitian}

Pada penelitian ini kuesioner yang disebarkan sebanyak 232 buah, di mana 32 di antaranya tidak memenuhi kriteria sehingga jumlah kuesioner yang digunakan untuk analisis adalah 200 buah. Untuk pengujian validitas dan reliabilitas digunakan 40 kuesioner.

\section{a. Uji Validitas}

Tabel I menunjukkan hasil uji validitas masing-masing dimensi, yakin relasi interpersonal dengan 8 item pernyataan, manajemen terapi dengan 8 item pernyataan, kepuasan umum dengan 4 item pernyataan, dan citra rumah sakit dengan 6 pernyataan. Seluruh dimensi menghasilkan nilai sig. lebih kecil dari nilai alpha 0,05 , maka tolak $\mathrm{H}_{0}$ dan terima $\mathrm{H}_{1}$, sehingga item relasi interpersonal, manajemen terapi, kepuasan umum, dan citra rumah sakit dinyatakan signifikan dan dapat digunakan untuk mengukur variabel yang diteliti. 
Tabel Ia. Hasil Uji Validitas Kuesioner

\begin{tabular}{ccccc}
\hline \multirow{2}{*}{ Nilai Sig. } & \multicolumn{2}{c}{ Relasi Interpersonal } & \multicolumn{2}{c}{ Manajemen Terapi } \\
\cline { 2 - 5 } & R.Hitung & Signifikansi & R.Hitung & Signifikansi \\
\hline $\mathbf{0 , 0 0 0}$ & 0,706 & 0,05 & 0,662 & 0,05 \\
$\mathbf{0 , 0 0 0}$ & 0,636 & 0,05 & 0,587 & 0,05 \\
$\mathbf{0 , 0 0 0}$ & 0,500 & 0,05 & 0,692 & 0,05 \\
$\mathbf{0 , 0 0 0}$ & 0,691 & 0,05 & 0,571 & 0,05 \\
$\mathbf{0 , 0 0 0}$ & 0,627 & 0,05 & 0,587 & 0,05 \\
$\mathbf{0 , 0 0 0}$ & 0,696 & 0,05 & 0,501 & 0,05 \\
$\mathbf{0 , 0 0 0}$ & 0,627 & 0,05 & 0,534 & 0,05 \\
$\mathbf{0 , 0 0 0}$ & 0,396 & 0,05 & 0,573 & 0,05 \\
\hline
\end{tabular}

Tabel Ib. Hasil Uji Validitas Kuesioner

\begin{tabular}{ccccc}
\hline \multirow{2}{*}{ Nilai Sig. } & \multicolumn{2}{c}{ Kepuasan Umum } & \multicolumn{2}{c}{ Citra Rumah Sakit } \\
\cline { 2 - 5 } & R.Hitung & Signifikansi & R.Hitung & Signifikansi \\
\hline $\mathbf{0 , 0 0 0}$ & 0,752 & 0,05 & 0,752 & 0,05 \\
$\mathbf{0 , 0 0 0}$ & 0,718 & 0,05 & 0,718 & 0,05 \\
$\mathbf{0 , 0 0 0}$ & 0,733 & 0,05 & 0,733 & 0,05 \\
$\mathbf{0 , 0 0 0}$ & 0,773 & 0,05 & 0,773 & 0,05 \\
\hline
\end{tabular}

Tabel II. Hasil Uji Reliabilitas Kuesioner

\begin{tabular}{lcc}
\hline \multicolumn{1}{c}{ Variabel } & Cronch Alpha & Keterangan \\
\hline Relasi Interpersonal & 0,749 & Reliabel \\
Manajemen Terapi & 0,742 & Reliabel \\
Kepuasan Umum & 0,792 & Reliabel \\
Citra Rumah Sakit & 0,766 & Reliabel \\
\hline
\end{tabular}

\section{Uji Reliabilitas}

Hasil uji reliabilitas menunjukkan bahwa instrument setiap variabel penelitian adalah reliabel, ditunjukkan dari $\alpha$ hitung $>0,7$ (Tabel II).

\section{Uji Normalitas}

Dari Tabel III dapat diketahui bahwa nilai sig. yakni sebesar 0,952 . Nilai sig. tersebut lebih besar dari 0,05, maka terima $\mathrm{H}_{0}$, sehingga dari pengujian ini diketahui bahwa data penelitian terdistribusi normal.

\section{Uji Heteroskedastisitas}

Dari Tabel IV didapatkan nilai Sig. untuk Relasi Interpersonal adalah 0.880, nilai Sig.untuk Manajemen Terapi adalah 0.172, dan nilai Sig.untuk Kepuasan Umum adalah 0.748. Pada hasil pengujian heteroskedastisitas disimpulkan bahwa $\mathrm{H}_{0}$ diterima dan $\mathrm{H}_{1}$ ditolak yang berarti di semua variabel independen tidak terjadi heteroskedastisitas.

\section{Uji Multikolinearitas}

Pada data penelitian ini tidak ditemukan multikolinearitas, terlihat dari tabel V bahwa nilai Tolerance dan VIF pada ketiga variabel telah memenuhi syarat pengambilan keputusan untuk uji multikolinearitas.

\section{Analisis Regresi Linear}

Dalam Tabel VI, nilai $Y$ mempresentasikan Citra Rumah Sakit yang hasilnya akan diperoleh dari perhitungan variabel relasi interpersonal (X1), manajemen terapi (X2), dan kepuasan umum (X3). 
Charina Halim Sugiono, et al

Tabel III. Hasil Uji Normalitas

\begin{tabular}{cc}
\hline & Unstandardized Residual \\
\hline Asymp. Sig. (2-tailed) &, 952 \\
\hline
\end{tabular}

Tabel IV. Hasil Uji Heteroskedastisitas

\begin{tabular}{|c|c|c|c|c|c|c|}
\hline \multicolumn{7}{|c|}{ Coefficients $^{\mathrm{a}}$} \\
\hline & \multirow{2}{*}{ Model } & \multicolumn{2}{|c|}{ Unstand. } & \multirow{2}{*}{$\begin{array}{c}\text { Standard } \\
\text { Beta }\end{array}$} & \multirow[b]{2}{*}{$\mathbf{t}$} & \multirow{2}{*}{ Sig. } \\
\hline & & B & Std. E & & & \\
\hline \multirow[t]{4}{*}{1} & $\mathrm{C}$ & 2,666 & 670 & & 3,980 & ,000 \\
\hline & RI &,- 004 & 024 &,- 013 &,- 151 &, 880 \\
\hline & MT &,- 039 & ,029 &,- 119 & $-1,369$ & 172 \\
\hline & $\mathrm{KU}$ &,- 013 & ,041 &,- 029 &,- 322 & ,748 \\
\hline
\end{tabular}

Tabel VIII. Hasil Uji F

\begin{tabular}{cl}
\hline $\mathbf{F}$ & Sig. \\
\hline 58,781 &, $000^{\mathrm{b}}$ \\
\hline
\end{tabular}

Tabel IX. Hasil Uji t

\begin{tabular}{|c|c|c|c|c|c|}
\hline \multirow{2}{*}{ Model } & \multicolumn{2}{|c|}{ Unstandard } & \multirow{2}{*}{$\begin{array}{c}\text { Standard } \\
\text { Beta }\end{array}$} & \multirow{2}{*}{$t$} & \multirow{2}{*}{ Sig } \\
\hline & B & Std. Error & & & \\
\hline $1 \mathrm{C}$ & 6,301 & 1,152 & & 5,470 & ,000 \\
\hline RI & 166 & ,042 & ,243 & 3,969 & ,000 \\
\hline MT & ,261 & ,050 & ,337 & 5,267 & ,000 \\
\hline KU &, 276 & ,071 & ,262 & 3,899 & ,000 \\
\hline
\end{tabular}

Dari analisis pada Tabel VII diperoleh hasil $\mathrm{R}$ square (koefisien determinasi) sebesar 0,474. Artinya bahwa $47 \%$ variabel Citra rumah sakit akan dipengaruhi oleh variabel bebasnya, yaitu relasi interpersonal (X1), manajemen terapi (X2), kepuasan umum (X3). Sedangkan sisanya variabel citra rumah sakit akan dipengaruhi oleh variabel-variabel yang lain yang tidak dibahas dalam penelitian ini.

Selain koefisien determinasi juga didapat koefisien korelasi yang menunjukkan besarnya hubungan antara variabel bebas yaitu relasi interpersonal (X1), manajemen terapi (X2), kepuasan umum (X3) dengan variabel citra rumah sakit, nilai $\mathrm{R}$ (koefisien korelasi) sebesar 0,688, nilai korelasi ini menunjukkan bahwa hubungan antara variabel bebas yaitu relasi interpersonal (X1), manajemen terapi $(\mathrm{X} 2)$, kepuasan umum $(\mathrm{X} 3)$ dengan variabel citra rumah sakit termasuk dalam kategori belum cukup kuat karena tidak berada pada rentang $0,8-1,0$.

\section{Uji F}

Hasil penelitian pada tabel VIII menunjukkan bahwa nilai sig. yang dihasilkan 0,000 , yang berarti lebih besar dari 0,05 , hal ini berarti $\mathrm{H}_{0}$ ditolak dan $\mathrm{H}_{1}$ diterima sehingga dapat disimpulkan bahwa variabel terikat yaitu Citra Rumah Sakit dapat dipengaruhi secara signifikan oleh variabel bebas (relasi interpersonal, manajemen terapi, kepuasan umum).

\section{Uji t}

Uji t digunakan untuk mengetahui apakah masing-masing variabel bebas secara parsial mempunyai pengaruh yang signifikan terhadap variabel terikat. Dasar pengambilan 
Tabel X. Hasil Kuesioner Pelayanan Kefarmasian Dimensi Relasi Interpersonal

\begin{tabular}{|c|c|c|}
\hline No & Relasi Interpersonal & Rating \\
\hline 1. & Tenaga kefarmasian peduli terhadap kondisi kesehatan anda & 3,265 \\
\hline 2. & Tenaga kefarmasian menunjukkan sikap yang profesional & 3,365 \\
\hline 3. & $\begin{array}{l}\text { Tenaga kefarmasian tidak menunjukkan sikap menghormati dan } \\
\text { menghargai }\end{array}$ & 0,365 \\
\hline 4. & $\begin{array}{l}\text { Tenaga kefarmasian memberikan saran terkait masalah yang } \\
\text { mungkin dapat terjadi saat pengobatan }\end{array}$ & 2,905 \\
\hline 5. & $\begin{array}{l}\text { Tenaga kefarmasian tidak memberi rekomendasi untuk } \\
\text { menghindari biaya yang tidak diperlukan }\end{array}$ & 0,86 \\
\hline 6. & Tenaga kefarmasian menyediakan waktu untuk berkonsultasi & 3,045 \\
\hline 7. & Tenaga kefarmasian menginformasikan cara meminum obat & 3,395 \\
\hline 8. & $\begin{array}{l}\text { Tenaga kefarmasian tidak menjawab pertanyaan saudara dengan } \\
\text { baik }\end{array}$ & 3,61 \\
\hline
\end{tabular}

keputusan dalam penelitian ini adalah jika nilai sig lebih kecil dari nilai probabilitas 0,05, maka $\mathrm{H}_{1}$ diterima dan $\mathrm{H}_{0}$ ditolak. Dari hasil pada tabel IX, hipotesis yang didapatkan yaitu nilai sig. relasi interpersonal 0,000 yang berarti lebih kecil dari nilai probabilitas 0,05, maka pengaruh $X_{1}$ (relasi interpersonal) terhadap citra rumah sakit adalah signifikan. Hal ini berarti $\mathrm{H}_{0}$ ditolak dan $\mathrm{H}_{1}$ diterima sehingga dapat disimpulkan bahwa citra rumah sakit dapat dipengaruhi oleh relasi interpersonal.

Uji $t$ antara $\mathrm{X}_{2}$ (Manajemen Terapi) dengan $Y$ (Citra rumah Sakit) menunjukkan nilai sig. manajemen terapi 0,000 yang berarti lebih kecil dari nilai probabilitas 0,05, maka pengaruh $\mathrm{X}_{2}$ (manajemen terapi) terhadap citra rumah sakit adalah signifikan. $\mathrm{Hal}$ ini berarti $\mathrm{H}_{0}$ ditolak dan $\mathrm{H}_{1}$ diterima sehingga dapat disimpulkan bahwa citra rumah sakit dapat dipengaruhi oleh manajemen terapi.

Uji $\mathrm{t}$ antara $\mathrm{X}_{3}$ (Kepuasan Umum) dengan Y (Citra Rumah Sakit) menunjukkan menunjukkan nilai sig. kepuasan umum 0,000 yang berarti lebih kecil dari nilai probabilitas 0,05, maka pengaruh $X_{3}$ (kepuasan umum) terhadap citra rumah sakit adalah signifikan. Hal ini berarti $\mathrm{H}_{0}$ ditolak dan $\mathrm{H}_{1}$ diterima sehingga dapat disimpulkan bahwa citra rumah sakit dapat dipengaruhi oleh kepuasan umum.

\section{Tingkat Kepuasan Pasien}

Tingkat kepuasan pasien didapatkan dari masing-masing pernyataan pada tiga dimensi pelayanan kefarmasian, yakni relasi interpersonal, manajemen terapi, kepuasan pasien secara umum. Berikut adalah hasil ratarata tingkat kepuasan pasien mengenai ketiga dimensi tersebut.

Setelah dihitung rata rata dari penilaian 200 responden pada dimensi citra rumah sakit, dapat dilihat bahwa pasien memberikan kepercayaan kepada Rumah Sakit Baptis untuk memberikan pelayanan yang terbaik. Penilaian pasien pada citra rumah sakit secara keseluruhan dapat disimpulkan baik, karena rata rata lebih dari 3 yang berarti pasien setuju dengan pernyataan baik mengenai citra rumah sakit. Dimensi tersebut telah mencangkup beberapa hal mengenai kepedulian tenaga kefarmasian terhadap pasien, etika tenaga kefarmasian yang ditunjukkan kepada pasien, penjaminan penggunaan obat secara benar dan tepat, pelayanan informasi obat, hingga melakukan diskusi mengenai tercapai tidaknya terapi yang diterima oleh pasien ${ }^{18}$.

Penelitian ini dilakukan dengan total responden 200 orang yang terbagi dalam $45 \%$ responden laki-laki dan 55\% responden perempuan. Mayoritas responden yang tergabung dalam penelitian ini berusia 17 hingga 35 tahun dengan prosentase $55 \%$. 
Tabel XI. Hasil Kuesioner Pelayanan Kefarmasian Dimensi Manajemen Terapi

\begin{tabular}{|c|c|c|}
\hline No & Manajemen Terapi & Rating \\
\hline 1. & $\begin{array}{l}\text { Keberadaan tenaga kefarmasian untuk menjawab pertanyaan } \\
\text { anda/ saudara }\end{array}$ & 3,375 \\
\hline 2. & $\begin{array}{l}\text { Cara tenaga kefarmasian menginformasikan aturan pakai } \\
\text { penggunaan obat }\end{array}$ & 3,515 \\
\hline 3. & $\begin{array}{l}\text { Upaya tenaga kefarmasian dalam memberi informasi tentang } \\
\text { terapi tambahan guna meningkatkan efektivitas obat }\end{array}$ & 2,92 \\
\hline 4. & $\begin{array}{l}\text { Tenaga kefarmasian menginformasikan tentang prosedur } \\
\text { penyimpanan obat dengan benar }\end{array}$ & 3,235 \\
\hline 5. & $\begin{array}{l}\text { Tenaga kefarmasian menginformasikan tentang masalah } \\
\text { (misalnya efek samping) yang mungkin terjadi terkait dengan } \\
\text { penggunaan obat }\end{array}$ & 2,88 \\
\hline 6. & $\begin{array}{l}\text { Tenaga kesehatan memberi informasi terkait hasil yang } \\
\text { diharapkan dari penggunaan obat }\end{array}$ & 2,97 \\
\hline 7. & $\begin{array}{l}\text { Bantuan dari tenaga kesehatan untuk menginformasikan terkait } \\
\text { administrasi }\end{array}$ & 2,905 \\
\hline 8. & $\begin{array}{l}\text { Cara tenaga kesehatan berdiskusi dengan anda untuk } \\
\text { merencanakan pengobatan }\end{array}$ & 2,895 \\
\hline
\end{tabular}

Tabel XII. Hasil Kuesioner Pelayanan Kefarmasian Dimensi Kepuasan Umum

\begin{tabular}{clc}
\hline No & Kepuasan Umum & Rating \\
\hline 1. & Privasi percakapan anda dengan apoteker & 3,225 \\
2. & Waktu yang dibutuhkan farmasis untuk menyelesaikan resep & 2,27 \\
3. & Apoteker berpenampilan professional & 3,195 \\
4. & Layanan apotek secara keseluruhan & 3,295 \\
\hline
\end{tabular}

Hal ini menunjukkan mayoritas responden berusia produktif. Dilihat dari tingkat pendidikan, responden pada penelitian ini memiliki jenjang pendidikan tertinggi yakni Strata I, namun dari 200 responden prosentase terbanyak pada jenjang pendidikan SLTA, hal ini berhubungan dengan standar pasien terhadap rumah sakit yang tidak terlalu tinggi, sehingga pasien dapat memberikan penilaian pelayanan kefarmasian rumah sakit dengan lebih objektif, selain itu dengan mengetahui prosentase terbesar tingkat pendidikan pasien adalah SLTA maka tenaga kefarmasian baiknya memberikan informasi yang cukup lengkap mengenai pengobatan pasien.

Prosentase terbanyak pada jenis pekerjaan responden yakni sebagai pegawai swasta dengan prosentase $25 \%$ yang setara dengan 49 responden dari 200 responden.
Dengan mengetahui prosentase jenis pekerjaan pasien maka dapat dinilai bahwa mayoritas pasien memiliki standar tentang profesionalitas dan pelayanan jasa sehingga membantu pasien dalam menilai pelayanan kefarmasian yang ada di Rumah Sakit Baptis. Prosentase dari tingkat penghasilan menunjukkan juga bahwa sebagian besar dari responden memiliki penghasilan Rp 1.000.000,- hingga Rp 3.000.000,- dalam satu bulan. Mayoritas masyarakat akan memilih rumah sakit atau tempat berobat sesuai dengan penghasilan yang mereka dapatkan, sehingga terciptalah ekspektasi pelayanan di suatu rumah sakit yang sesuai dengan kemampuan financial para pasien, selain itu dengan adanya program BPJS maka dapat diketahui masyarakat memanfaatkan program tersebut dan memilih 
Tabel XIII. Hasil Kuesioner Pelayanan Kefarmasian Dimensi Citra Rumah Sakit

\begin{tabular}{cll}
\hline No & Citra Rumah Sakit & Rating \\
\hline 1. & $\begin{array}{l}\text { Saya percaya bahwa RS. Baptis Batu memberikan pelayanan yang } \\
\text { terbaik }\end{array}$ & 3,565 \\
2. $\quad \begin{array}{l}\text { Pelayanan kesehatan RS. Baptis Batu tidak memiliki reputasi yang } \\
\text { baik di masyarakat }\end{array}$ & 3,38 \\
3. $\quad \begin{array}{l}\text { RS. Baptis Batu selalu menjadi rumah sakit yang pertama kali muncul } \\
\text { dalam pikiran saya dan saya pilih, bila ingin berobat atau dirawat } \\
\text { pada suatu rumah sakit }\end{array}$ & 3,255 \\
$\begin{array}{l}\text { Saya sangat terkesan dengan pelayanan kesehatan di RS. Baptis Batu } \\
\text { yang sangat memuaskan }\end{array}$ & 3,3 \\
$\begin{array}{l}\text { Saya tidak akan menceritakan kesan yang baik selama saya } \\
\text { mendapatkan pelayanan kesehatan di RS. Baptis Batu kepada orang } \\
\text { lain }\end{array}$ & $\begin{array}{l}\text { Saya akan merekomendasikan kepada orang lain untuk berobat ke RS. } \\
\text { Baptis Batu }\end{array}$ & 3,415 \\
\hline
\end{tabular}

Rumah Sakit Baptis untuk membantu proses pengobatannya.

Skala kunjungan Instalasi Farmasi juga menjadi salah satu kriteria dalam penentuan responden pada penelitian ini. Responden yang masuk dalam kriteria penelitian ini harus sudah pernah mendapatkan pelayanan kefarmasian Instalasi Farmasi Rawat Jalan RS. Baptis Batu sebanyak 2 kali dan pernah mendapatkan pelayanan farmasi di instalasi farmasi rumah sakit lain minimal satu kali. Kriteria ini dibuat agar penilaian responden terhadap pelayanan kefarmasian di Instalasi Farmasi RS. Baptis Batu sesuai dengan apa yang responden rasakan dan terima, selain itu dengan adanya kriteria skala kunjungan di farmasi rumah sakit lain responden juga dapat membandingkan kualitas pelayanan yang di berikan oleh kefarmasian RS. Baptis dengan rumah sakit yang lainnya, sehingga jawaban atau penilaian yang diberikan bersifat objektif.

Mengacu pada hasil penelitian yang telah dilakukan, dapat diketahui bahwa ketiga hipotesis memiliki pengaruh terhadap perubahan citra rumah sakit, yakni variabel relasi interpersonal, manajemen terapi, dan kepuaasan secaara umum. Bila dilihat secara simultan, ketiga variabel secara bersamaan memberikan pengaruh terhadap citra rumah sakit. Pengujian hipotesis Uji F dilakukan untuk menjawab hipotesis penelitian mengenai apakah variabel relasi interpersonal, manajemen terapi, kepuasan umum mempengaruhi citra rumah sakit secara signifikan atau tidak. Hasil pengujian ini dapat dilihat pada Tabel 4.24. Pada tabel di atas diketahui bahwa bahwa nilai sig. yang dihasilkan dalam uji $\mathrm{F}$ yakni 0,000, yang berarti lebih besar dari 0,05, hal ini berarti $\mathrm{H}_{0}$ ditolak dan $\mathrm{H}_{1}$ diterima sehingga dapat disimpulkan bahwa variabel terikat (Citra Rumah Sakit) dapat dipengaruhi secara signifikan oleh variabel bebas (relasi interpersonal, manajemen terapi, kepuasan umum). Kedua persyaratan tersebut telah terpenuhi dengan baik dan menjukkan bahwa Ho ditolak dan $\mathrm{H}_{1}$ diterima. Artinya bahwa terdapat pengaruh signifikan oleh variabel relasi interpersonal, manajemen terapi, kepuasan umum secara simultan terhadap citra rumah sakit.

Hasil ini juga diperkuat dari hasil perhitungan koefisien determinasi pada tabel 4.23, bahwa $47,4 \%$ variabel citra rumah sakit dipengaruhi oleh variabel bebasnya, yaitu relasi interpersonal, manajemen terapi, kepuasan umum, sedangkan $52,6 \%$ lainnya disebabkan oleh variabel lain yang tidak dibahas dalam penelitian ini. Selain koefisien determinasi dapat dilihat dari nilai $R$ 
Tabel Xa. Hasil Perumusan strategi SWOT

\begin{tabular}{|c|c|c|}
\hline Faktor eksternal & $\begin{array}{l}\text { Kekuatan (S) } \\
\text { - Adanya pengaturan organisasi } \\
\text { dan manajemen yang teratur } \\
\text { - Kesediaan tenaga farmasi dalam } \\
\text { memberikan edukasi dan } \\
\text { konseling } \\
\text { - Tenaga kefarmasian berperilaku } \\
\text { professional } \\
\text { - Alur pelayanan dan penataan } \\
\text { obat rapi, efektif, dan efisien } \\
\text { - Teknologi yang berkembang } \\
\text { mempermudah pelayanan } \\
\text { kepada pasien }\end{array}$ & $\begin{array}{l}\text { Kelemahan (W) } \\
\text { - Kurangnya tenaga kefarmasian } \\
\text { dengan jenjang pendidikan } \\
\text { khusus farmasi klinis } \\
\text { - Waktu tunggu obat pasien masih } \\
\text { cukup lama di Instalasi Farmasi } \\
\text { - Pendataan stok obat pada } \\
\text { komputer kurang relevan dengan } \\
\text { stok fisik } \\
\text { - Fasilitas instalasi farmasi kurang } \\
\text { memadai } \\
\text { - Kurangnya informasi mengenai } \\
\text { efek samping penggunaan obat }\end{array}$ \\
\hline \begin{tabular}{lr}
\multicolumn{2}{|l}{ Peluang (O) } \\
- Pertumbuhan & ekonomi \\
masyarakat kian membaik \\
- Perkembangan & teknologi \\
penunjang & pelayanan \\
farmasi & \\
- Kepercayaan & pasien \\
terhadap & pelayanan \\
kefarmasian di rumah sakit \\
- Adanya pangsa pasar yang \\
potensial \\
- Kebijakan \\
dengan adanya program \\
BPJS pemerintah
\end{tabular} & $\begin{array}{l}\text { Strategi S-O } \\
\text {-Menggencarkan } \\
\text { promosi rumah sakit dengan } \\
\text { memanfaatkan perkembangan } \\
\text { teknologi } \\
\text {-Meningkatkan ilmu tenaga } \\
\text { kefarmasian dalam bidang } \\
\text { edukasi konseling yang } \\
\text { merupakan tugas utama tenaga } \\
\text { kefarmasian serta mingkatkan } \\
\text { perilaku professional. Kedua hal } \\
\text { tersebut ditunjang melalui } \\
\text { seminar atau pelatihan yang } \\
\text { ditujukan untuk tenaga } \\
\text { kefarmasian }\end{array}$ & $\begin{array}{l}\text { Strategi W-O } \\
\text {-Memperbaiki sistem informasi, } \\
\text { melakukan monitoring dan } \\
\text { evaluasi mengenai pendataan stok } \\
\text { fisik obat dan data computer } \\
\text { - Meningkatkan fasilitas di instalasi } \\
\text { farmasi yang memungkinan } \\
\text { memberi pengaruh pada waktu } \\
\text { tunggu obat pasien } \\
\text {-Mendorong pasien agar aktif } \\
\text { bertanya mengenai obat yang } \\
\text { dikonsumsi hingga efek samping } \\
\text { yang mungkin terjadi, melalui } \\
\text { program promosi kesehatan }\end{array}$ \\
\hline $\begin{array}{l}\text { Ancaman (T) } \\
\text {-Pertumbuhan rumah sakit } \\
\text { pesaing } \\
\text { - Kebijakan rumah sakit } \\
\text { dengan adanya program } \\
\text { BPJS perihal pemetaan obat } \\
\text { pulang pasien yang terbatas } \\
\text { pada rumah sakit swasta } \\
\text { - Proses pengadaan obat dari } \\
\text { distributor yang seringkali } \\
\text { terhambat } \\
\text { - Pelayanan farmasi klinis } \\
\text { yang dijalankan oleh } \\
\text { beberapa rumah sakit } \\
\text { Perkembangan teknologi } \\
\text { medis sebagai komponen } \\
\text { utama knowledge based } \\
\text { treatment }\end{array}$ & $\begin{array}{l}\text { Strategi S-T } \\
\text { - Mempertahankan dan } \\
\text { meningkatkan pelayanan } \\
\text { kefarmasian dari segi kualitas } \\
\text { sumber daya manusia dan sistem } \\
\text { yang dijalankan untuk bersaing } \\
\text { dengan rumah sakit lainnya di } \\
\text { Kota Batu dan sekitarnya } \\
\text { - Peningkatan manajemen } \\
\text { pengadaan obat dengan } \\
\text { pengaturan sistem pengajuan } \\
\text { pengadaan obat teknologi yang } \\
\text { Meningkatkan membuat } \\
\text { berkembang untuk mas } \\
\text { sarana informasi terapi berbasis } \\
\text { teknologi untuk pasien. }\end{array}$ & $\begin{array}{l}\text { Strategi W-T } \\
\text { - Mengadakan pelatihan untuk } \\
\text { farmasi klinis } \\
\text { - Mencari tenaga kefarmasian } \\
\text { khusus dibidang farmasi klinis }\end{array}$ \\
\hline
\end{tabular}


korelasi ini menunjukkan bahwa hubungan antara variabel bebas yaitu relasi interpersonal, manajemen terapi, kepuasan umum dengan citra rumah sakit termasuk dalam kategori belum cukup kuat karena tidak masuk dalam rentang 0,8-1,0.

Menurut teori yang dikemukakan Polat, kualitas dari jasa yang diberikan kepada konsumen, yang pada penelitian ini adalah pasien akan mempengaruhi positif dan negatifnya suatu citra rumah sakit, maka pelayanan yang buruk dapat merubah citra perusahaan dari positif menjadi citra yang dipandang negatif5. Pada kuesioner yang dibagikan terdapat 3 dimensi yang mewakili pelayanan dari suatu instalasi kefarmasian yakni relasi interpersonal, manajemen terapi dan kepuasan secara umum. Dari data yang telah didapatkan diketahui bahwa dimensi kepuasan secara umum yang diantaranya yakni menilai profesionalitas tenaga kefarmasian, waktu tunggu obat, dan layanan kefarmasian rawat jalan secara keseluruhan memiliki pengaruh yang paling tinggi pada citra rumah sakit. setelah kepuasan secara umum, dimensi manajemen terapi yang diantaranya menilai dari sisi bagaimana tenaga kefarmasian memberikan perhatian pada proses pengobatan/terapi pasien hingga pasien mencapai kondisi yang baik memiliki pengaruh yang cukup tinggi bagi citra rumah sakit. Dimensi yang terakhir yakni relasi interpersonal yang memiliki pengaruh juga bagi citra rumah sakit, hal ini lebih kepada bagaimana tenaga kefarmasian menjalin hubungan dengan pasien, bagaimana tenaga kefarmasian memberikan komunikan yang baik sehungga outputnya adalah terciptanya pelayanan yang nyaman bagi pasien.

\section{KESIMPULAN}

Hasil yang didapatkan dari data kuesioner secara keseluruhan, menyatakan bahwa ketiga dimensi memiliki respon yang baik dari pasien dengan respon terbaik ada pada dimensi kepuasan umum. Hal ini membuktikan bahwa secara analisa data kuantitatif tenaga kefarmasian di Instalasi Farmasi Rawat Jalan RS. Baptis Batu sudah memberikan pelayanan yang baik, memberikan kepedulian terhadap pasien, menunjukkan sikap menghormati dan memberi kesediaannya untuk kegiatan informasi, edukasi, konseling dengan baik. Sementara itu rating yang tergolong rendah, tetapi masih pada rentang baik adalah waktu tunggu obat pasien yang berada dalam dimensi kepuasan pasien secara umum. Selain menilai tingkat kepuasan pasien terhadap pelayanan kefarmasian, penelitian ini juga menilai pengaruh masing-masing dimensi pada pelayanan kefarmasian terhadap citra Rumah Sakit Baptis Batu. Jika pengaruh dilihat secara simultan, maka ketiga variabel independen berpengaruh signifikan terhadap citra Rumah Sakit Baptis Batu, meski nilai signifikansinya tergolong rendah. Begitu pula bila dilihat secara parsial, masing-masing variabel yakni relasi interpersonal, manajemen terapi dan kepuasan pasien secara umum berpengaruh positif terhadap citra rumah sakit, yang berarti citra rumah sakit akan naik ketika rumah sakit dapat memberikan pelayanan kefarmasian sesuai dengan ketiga dimensi tersebut. Analisis SWOT RS. Baptis Batu yang dilakukan peneliti menunjukkan rumah sakit berada pada kuadran satu, artinya bahwa rumah sakit menjalankan strategi yang mengarah kepada pertumbuhan rumah sakit, yang berarti rumah sakit berada pada posisi sempurna sehingga dapat mengandalkan kekuatan yang dimiliki untuk berkembang dengan pesat.

\section{DAFTAR PUSTAKA}

1. Wang G., Lee Y., Chang J. Correlations among Brand Image, Dynamic Capability, Knowledge Management Capability and Competitive Advantage. 2016;5(4):34-42.

2. Singh PP. Comparison of Service Quality between Private and Public Hospitals: Empirical Evidences from Varanasi District in up. Paradigm. 2015;17(1-2):37-46.

3. Soltani M., Esfidani MR., Jandaghi G., Soltaninejad N. The Effect of Service Quality on Private Brand Image and 
Purchase Intention in The Chain Stores of ETKA. World Sci News. 2016;47(2):202-216.

4. Umam S., Handayani SD., Aini Q. Pengaruh Kualitas Jasa Pelayanan Terhadap Citra Instalasi Radiologi di Rumah Sakit Gigi dan Mulut Pendidikan Universitas Muhammadiyah Yogyakarta. J Medicoeticolegal dan Manaj Rumah Sakit. 2014;3(2):1-17.

5. Polat., S., Abat, E., and Tezyurek S. The Perceived Corporate Image of Private Secondary Schools By Students ' and. Eur J Educ Stud. 2010;2(2):65-76.

6. Wu PCS., Yeh GYY., Hsiao CR. The effect of store image and service quality on brand image and purchase intention for private label brands. Australas Mark $J$. 2011;19(1):30-39. doi:10.1016/j.ausmj.2010.11.001

7. Laohasirichaikul B., Chaipoopirutana S., Combs H. Effective Customer Relationship Management of Health Care: A Study of Hospitals in Thailand. J Manag Mark Res. 2011;6(1):1-12. www.thannews.th.

8. Wu C-C. The Impact Of Hospital Brand Image On Service Quality, Patient Satisfaction And Loyalty. African J Bus Manag. 2011;5(12):4873-4882.

9. Sibarani T., Riani AL. The Effect of Health Service Quality and Brand Image on Patients Loyalty, With Patients Satisfaction as Mediating Variable (A Study in VIP Ward of Prof Dr R Soeharso Ortopedics Hospital in Surakarta). Sebel Maret Bus Rev.
2017;2(1):25-42.

10. Kotler P., Keller KL. Marketing Management. Vol 13.; 2009.

11. Dominici G., Guzzo R. Customer Satisfaction in the Hotel Industry: A Case Study from Sicily. Int J Mark Stud. 2014;2(2):2-12.

12. Tjoe TF., Sarjono H. Strategi Bisnis pada PT CTL Dengan Pendekatan Metode Tows. Binus Bus Rev. 2010;1(2):434.

13. Sugiyono. Metode Penelitian Manajemen. Bandung: Alfabeta; 2016.

14. Larson LN., Rovers JP., MacKeigan LD. Patient Satisfaction with Pharmaceutical Care: Update of a Validated Instrument. J Am Pharm Assoc (Washington, DC 1996). 2009;42(1):44-50.

15. Okpalanma NN., Okonta MJ., Ilodigwe EE. Development and validation of questionnaire for the assessment of pharmaceutical care by community pharmacists in a State in Nigeria. J Biol Agric Healthc. 2013;3(7):16-25.

16. Ghozali I. Aplikasi Analisis Multivariat Dengan Program SPSS. Semarang: Universitas Diponegoro; 2009.

17. Ekiz EH., I-shou U., T D, Rd S. Mapping Out Factors Constraining Tourist Complaints : Hints For Managers Who Wish To Hear More. Asian J Bus Manag. 2009;1(1):6-18.

18. Traverso ML., Salamano M., Botta C., Colautti M., Palchik V., Pérez B. Questionnaire to assess patient satisfaction with pharmaceutical care in Spanish language. Int J Qual Heal Care. 2011;19(4):217-224. 